\title{
Az egészségtudatos vállalati magatartás fejlesztésének diagnosztikai modellje
}

\section{Diagnostic Model for Supporting the Development of Health-conscious Organizational Behavior}

\author{
M. KAROLINY \\ Pécsi Tudományegyetem, Közgazdaságtudományi Kar, karoliny@ktk.pte.hu
}

\begin{abstract}
Absztrakt. A 21. században a világ egyre több országában vallják, hogy az emberek egészsége nem csak az egészségügy, hanem életük jelentős színtereinek ügye. A munkavállalók esetében ilyen színtér a munkahely. A munkavállalók egészségének és testi épségének védelme Európában rég óta a munkáltató át nem hárítható (objektív) feladata és felelössége. Az egészség és a munkahely mai kapcsolat- és szempont- és eszközrendszere azonban már lényegesen túlmutat a munkahelyi egészség és biztonság hagyományos területein. Az egészségtudatos vállalati magatartás fejlesztése a hazai szervezetek sokasága számára jelent olyan kihívást, melyben a tanulmányban bemutatott modell mind helyzetük diagnosztizálásához, mind pedig a fejlesztés irányának, módjának és eszközrendszerének testreszabott megválasztásához segítséget adhat.
\end{abstract}

Abstract. In the 21st century more and more countries of the world take the attitude that human health is not just an issue for healthcare services but for all major areas of life. Such an area for employees is the workplace. Protection of employee health and safety has for a long time been a non-transferable (objective) obligation and responsibility for employers in Europe. Connections between health and the workplace have however extended far beyond the traditional aspect of safety and health at work. Developing a health-conscious organisational behaviour means a challenge for many Hungarian companies; the model described in this study assists them in both diagnosing their current situation and choosing the appropriate course, method and tools for development.

\section{Bevezetés}

A világ eltérő kulturális értékeket követő közösségeihez tartozó emberek sokasága egymáshoz hasonlóan vallja, a legnagyobb kincs: az egészség. A gazdaságilag fejlett világ vállalatvezetőinek pedig egyre nagyobb hányada állítja, hirdeti, hogy szervezetének legértékesebb erőforrásai: az emberek.

Az emberek egészségét a 21. században a világ egyre nagyobb részén nem csak az egészségügy, hanem azon színterek ügyeként kezelik, ahol az emberi élet jelentős része zajlik. A munkavállalók esetében ilyen színtér a munkahely. A vállalkozások, intézmények ugyanis közvetlen hatást fejtenek ki az emberek egészségére és az egészséget meghatározó tényezőkre is. A munkavállalók egészségének és testi épségének védelme Európában régóta a munkáltatók feladata és felelőssége. Az öregedő Európában pedig az egészséges öregedés biztosítása az egészség védelmét, a megelőzés kultúrájának 
kialakítását és fejlesztését, a cégek egészségmagatartásának formálását az érdemi vállalatvezetői feladatok közé állítja.

Így sok szempontból elvitathatatlan, hogy az egészségtudatos vállalati magatartás a 21. századi Európában működő magyar vállalkozások számára is új kihívásokat teremt.

\section{Az egészségtudatos vállalati magatartást érintő nemzetközi és európai kezdeményezések a 21. században}

Az egészség és a munkahely kapcsolatrendszerében a két témakört világszinten képviselő csúcsszervezetekhez - a Nemzetközi Munkaügyi Szervezet, az (ILO)ésaz Egészségügyi Világszervezet (WHO) - mind múltjuk, mind pedig 21. századi felvetéseik révén kiemelkedő szerep kapcsolódik.

Az ENSZ szakosodott szervezete, az ILO 1919-es megalakulása óta központi kérdésként kezeli a megfelelő, biztonságos és egészséges munkafeltételek ügyét. A majd száz éves müködése során megszületett egyezmények, ajánlások mintegy fele teljes egészében, vagy részben kapcsolódott a foglalkozási-, ill. munkahelyi egészség és biztonság (ME\&B) területeihez.

A WHO e témakörben betöltött meghatározó szerepe pedig abból következik, hogy egyrészt alkotmányában kimondja, hogy: „minden ember alapvető joga az elérhető legmagasabb színvonalú egészségügyi ellátás." Az alkotmány második fejezetének 2. cikkelye szerint pedig a WHO felelös a baleseti sérülések megelőzésében és a munkakörülmények javításában és fejlesztésében is.

Miközben az ILO törekvései hatására az elmúlt több, mint90 év alatt nemzeti szinteken a törvények és szabályok sokasága született, a 21. század első évtizedében megállapítást nyert, hogy a még mindig fennálló problémák miatt a nemzeti MEB rendszerek erősítése érdekében további koordinált nemzetközi akciókra is szükség van. E miatt született meg az ILO 2010-2016-os időszakra vonatkozó akcióterve, melynek stratégiai céljai között találjuk, hogy az egyes országok MEB politikája és akcióprogramjai közelítsenek az ILO standardjaihoz. Ennek érdekében újabb stratégiai célokat és akciókat definiáltak, melynekfőbb elemei többségében vállalati szintű akciók is körvonalazódnak. Olyanok, mint pl.:

1. A megelőzésre fókuszáló egészség és biztonság kultúra fejlesztésének támogatása, népszerűsítése, melynek vállalati szintű alakítása vállalatvezetői feladat.

2. A MEB kulcselemek mind szélesebb körű ratifikálásának és alkalmazásának támogatása. Vállalati szinten e tekintetben olyan akciókat támogatnak, melyek:

- az irányítási rendszer közelítés(MEBIR) alkalmazását propagálják,

- a munkások, MEB képviselőik és a vezetők, a munkáltatók képzési programokban való együttes bevonását ösztönzik,

- kézikönyvek és módszerek ajánlásával segítik a MEB gyakorlati munkáját.

3. Egyéb, a MEB hatását erősítő akciók, köztük: 
- a vállalati MEB irányítási rendszereinek folyamatos fejlesztését támogató Plan-Do-Check-Act modell kínálta lehetőségek kihasználása.

A WHO újabb keletű kezdeményezései közül vizsgált témakörünkben három kiemelkedő jelentőségű érdemel külön említést. Ezek az 1986-ban született Ottawai és a 2005-ös Bangkoki Charta, valamint 2007-ben elfogadott, a 2008-2017 időszakra szóló, a Munkások egészségére vonatkozó globális akcióterv.

Az Ottawai Chartát sokan tartják az egészség és a munkahely összekapcsolásában fordulópontnak az olyan ott született új definíciók és megállapítások miatt, mint pl., hogy:

- az egészség nem csupán a betegségek hiányaként jellemezhető;

- az egészség támogatása az egészséghez vezető új útként értelmezendő;

- az új egészségpolitikának fontoshelyszínei, színterei az iskolák és a munkahelyek.

Bangkoki Chartánakmáig ható jelentőségű az a megállapítása, mely szerint:,az egészség javítása érdekében megteendő egyik legfontosabb lépés azzal valósul meg, haaz egészség támogatása a jó vállalati gyakorlat részévé válik."A vállalati szektor ugyanis közvetlen hatást fejt ki az emberek egészségére és az egészséget meghatározó tényezőkre is. A munkáltatók így felelősséggel tartoznak a munkahelyi biztonságért és egészségért, emellett pedig alkalmazottaik, azok családja, valamint a közösség egészségének és jól-létének előmozdításáért is.

Természetesen az Európai Közösség is kinyilvánította az egészség iránti elköteleződését. Az EU Szerződés 137. cikkének (118/A) munkavédelmi alapelve szerint: az egészséget nem veszélyeztető és biztonságos munkavégzés kialakítása és fenntartása, a munkavállaló és környezete közötti kölcsönhatás átfogó és együttes kezelése, a munkavállalók egészségének és testi épségének védelme a munkáltató át nem hárítható (objektív) feladata és felelőssége.

Az EU-ban az egészségtudatos vállalati magatartáshoz kapcsolódóan az új évezred első évtizedének végén két kiemelkedő fontosságú dokumentum született: a Fehér Könyv és a Luxemburgi Deklaráció. Megvalósításukban kiemelkedő szerepet tölt be az EU-OSHA, az Európai Munkahelyi Biztonsági és Egészségvédelmi Ügynökség.

Miközben a Fehér Könyv az európai öregedő társadalomban kritikus kérdéssel, az egészség védelmével, az egészséges öregedés támogatásával foglalkozik általában, addig Luxemburgi Nyilatkozat kifejezetten a munkahelyi egészségre, egészségtámogatásra fókuszál, de a hagyományos munkahelyi egészség és biztonság (MEB, a hagyományos hazai megnevezése szerint munkaegészség és munkavédelem) közelítésnél tágabb értelemben.

A Luxemburgi Nyilatkozat szerint ugyanis a munkahelyi egészség támogatása (angolul: Workplace Health Promotion, WHP) a munkaadók, a munkavállalók, és a társadalom olyan együttes erőfeszítése, amely a munkások egészségének és jól-létének javítására irányul.

A Health Promotion (azaz az egészségtámogatás) a hazai szakmai szóhasználatban egészségfejlesztés megnevezést kapott. E helyett e tanulmány a továbbiakban az egészségtámogatás kifejezést használja. Így ugyanis jól megkülönböztethető az egészségfókuszú vállalati magatartás két típusa: 
- a munkahelyi egészség és biztonság (MEB) folyamatos javításának támogatása, valamint

- az egészség munkahelyi támogatásának (EMT), propagálásának, reklámozásának részben az egyénekre fókuszáló, részben szervezeti sajátosságokat érintő tennivalói.

A Luxemburgi Nyilatkozatbeli WHP, azaz a munkahelyi egészség támogatása (MET) mindkét területet (MEB+EMT) magában foglalja, a dokumentum szerint a munkahelyi egészség támogatásának (MET) főbb elemei és jellemzői a következők:

1. A MET: a jövőbe történő szervezeti befektetés, ugyanis a tradicionális MEB-el szemben (amely a munkahelyi egészséget a balesetek és a foglalkozási megbetegedések csökkentése révén javította), a MET olyan modern vállalati stratégia, amely:

- nemcsak a dolgozók egészségkárosodásának megelőzésére (beleértve a munkavégzéshez kapcsolódó betegségeket, baleseteket, sérüléseket, foglalkozási bántalmakat és a stresszt), hanem

- a munkatársak egészség-támogató potenciáljának erősítésére és jól-létük fokozására is törekszik.

2. A MET: egészséges emberek egészséges szervezetekben. A munkahely és az egészség kapcsolata többirányú. Károsíthatja azt, amennyiben egészségre káros munkafeltételek között kell dolgozni, a rendelkezésre álló készségek nem megfelelőek, ha hiányzik a kollégáktól jövő támogatás. Ugyanakkor a munka a személyes fejlődés és az egyéni készségek, kompetenciák fejlődésének forrása is lehet. A MET számos olyan munkahelyi tényezőt felölel, amely javítja a munkavállalók egészségét. Ezek a dokumentum szerint a következő:

- Olyan vezetői elvek és módszerek alkalmazása, amelyek a munkatársakat csupán költségfaktor helyett sikertényezőként kezelik - ami egyúttal a stratégiai emberi erőforrás (HR) menedzsment egyik is alapjellemzője közé tartozik.

- A munkavállalói részvételre építő, a minden munkatárs motivációját és felelősségét támogató szervezeti kultúra és vezetési elvek használata - amelyek szintén a felvilágosult vezetők által támogatott és a korszerű HR munkát igénylő gyakorlat jellemzői is.

- Olyan szervezeti alapelvek érvényesítése, amelyek egyensúlyteremtési lehetőséget adnak a munkavállalóknak olyan elemek között, mint a munkaelvárások, a saját munka feletti kontroll, a szakértelemszint és a társas támogatás.

- Az aktív egészségfejlesztést magában foglaló személyzeti (HR) politika.

- Az egészség és biztonság integrált szolgáltatásai.

3. A MET: bizonyítékon alapuló és sikeres. Ennek érdekében kitűzött céljai eléréséhez a következő útmutatók, jellemzők szerinti múködésre van szükség:

- minden munkatárs bevonása, részvétele (participáció);

- a szervezet minden területének minden fontos döntésében megjelenik (integráció);

- minden program szisztematikusan, a problémamegoldó ciklus elemeit (igényelemzés, prioritásképzés, tervezés, megvalósítás, folyamatos kontrollálás és értékelés, azaz a P-D-C-A elvet) alkalmazva múködik;

- a mérő-, értékelő-eszközök egyénre és környezetre irányuló beavatkozásokat is tartalmaznak és kombinálják a kockázatcsökkentés, valamint az egészségpotenciál és a védelmi tényezők fejlesztésének stratégiáit (széleskörű, átfogó jellegű). 


\section{Az egészségtudatos vállalati magatartás gyakorlatáról tanúskodó tények és vélemények Európáról és Európáról}

Az EK első egészségügyi stratégiai dokumentumában, a Fehér Könyvben olvasható megállapítások szerint 2050-re az EU lakosságán belül a 65 évnél idősebbek száma 70\%-kal fog nőni. A 80 évnél idősebbek száma pedig 170 \%-kal. Ezek a változások valószínűleg megnövelik az egészségügyi ellátás terheit, miközben a népességben a dolgozók aránya csökken. Ez a tagállamok egészségügyi kiadásait 2050-re a GDP 1-2\%-ával megemelheti, ami átlagosan az egészségügyi kiadások 25\%-os GDP-arányos növekedésének felel meg. A Bizottság előrejelzései azonban azt mutatják, hogy ha az emberek megőrzik egészségüket a hosszabb élet során, az öregedő népesség okozta egészségügyi kiadások akár feleződhetnek is.

Részben az előzőekről tanúskodnak az egészségügyi helyzet sokáig fő indikátoraként használt mutató alakulását a 1. ábrán szemléltető diagramok is, melyeken az látható, hogy új évezred első évtizedében (2002-2011) Európa országaiban mind a nők, mind a férfiak születéskor várható élettartama növekedett. A diagramokról ugyanakkor az is leolvasható, hogy a közép-kelet-európai volt szocialista országok - köztük Magyarországgal - a rangsor első harmadában található, az EU27-es átlagnál alacsonyabb várható élettartamokkal.

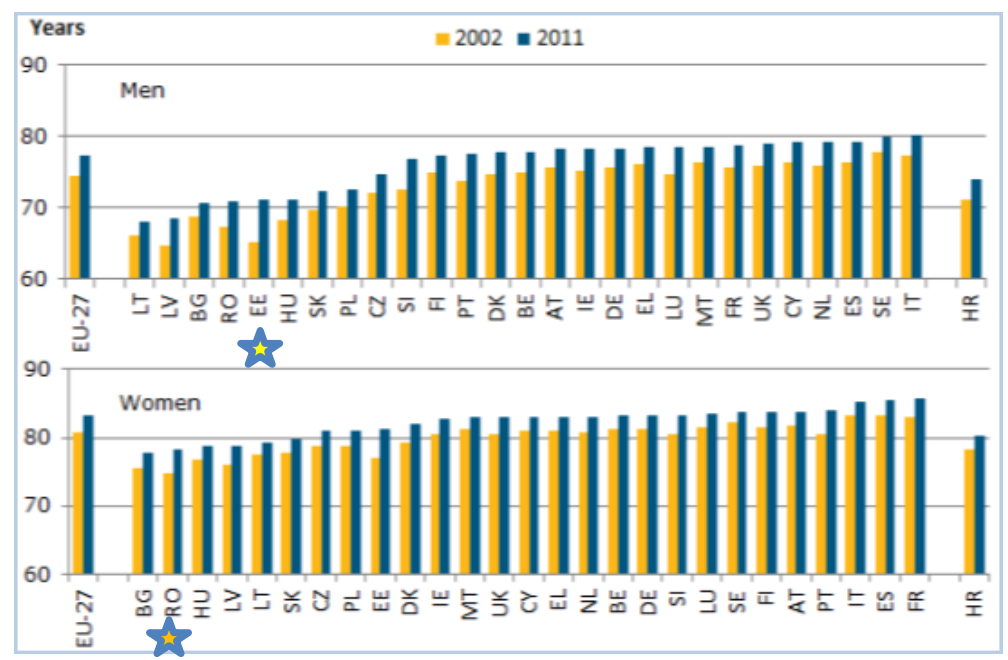

1. ábra: A férfiak és a nők születéskor várható élettartamának alakulása 2002-2011

(Forrás: Eurostat (online datacode: demo_mlexpec) Megj: EU-27, BE and IT: 2011 becsült adatok)

Az EU munkahelyi egészséggel és biztonsággal kapcsolatos, 2014-2020-as stratégiájában hivatkozott statisztikák és felmérések szerint a balesetek számának jelentős csökkenése és a jobb megelőzés ellenére:

- Évente több mint 4000 munkavállaló hal meg munkahelyi balesetek következtében, és több mint három millió munkavállaló szenved három munkanapnál hosszabb hiányzást indokoló súlyos munkahelyi balesetet. 
- A munkavállalók 24,2 \%-a gondolja, hogy egészsége és testi épsége a munkahelyén veszélyben van, és 25\%-a nyilatkozott arról, hogy a munka negatívan befolyásolja az egészségét.

- Az emberi szenvedésen túl a munkahelyi betegszabadság költségei elfogadhatatlanul magasak. Németországban a 460 millió nap/év betegszabadság - a becslések szerint - a bruttó nemzeti össztermék mintegy 3,1 \%-kal való csökkenéséhez vezetett.

- A betegségekből és balesetekből adódó társadalombiztosítási kiadások is elfogadhatatlanul magasak. A 2010/11-es pénzügyi évben az Egyesült Királyságban csak a kormányt terhelő nettó költséget mintegy 2381 millió angol fontra becsülték.

Az évezred eleji Európáról szóló EU OSHA által készített felmérésbeli véleményeket összegző megállapítások pedig a következőképpen szólnak:

- Az európai vállalatok mind az általános munkahelyi biztonsági és egészségvédelmi kérdések, mind pedig a pszichoszociális kockázatok kezelése terén jellemzően formális (szakpolitikai vagy folyamatalapú) intézkedéseket alkalmaznak, a munkahelyi egészség, jól-lét és biztonság irányítását szisztematikusan közelítik, ám kevésbé formális ( $\mathrm{ad}$ hoc) intézkedésekhez is folyamodnak, különösen akkor, ha pszichoszociális kockázatokról van szó.

- A formális politikák, megoldások a nagyobb vállalatoknál és az országokat tekintve Írországban, az Egyesült Királyságban, Hollandiában és a skandináv országokban jellemzőbbek, mint a dél-európai és a közép-kelet-európai országokban.

- A munkahelyi biztonsággal és egészségvédelem terén az európai vállalatoknál a balesetek, a váz- és izomrendszeri megbetegedések, valamint a munkahelyi stressz okozza a legtöbb aggodalmat. A felmérés szerint az erőszak, de különösen a durvaság és a zaklatás a vállalatok igen nagy részénél jelentős probléma.

- A felsővezetői elkötelezettséget és a középvezetők részvételét a megfelelő munkahelyi biztonsági és egészségvédelmi gyakorlatok kialakítása és végrehajtása kulcselemeinek tartják.

- Az egészségi és biztonsági kockázatok kezelésének fő mozgatóereje a jogi kötelezettségek teljesítése valamint a munkavállalók közvetlen vagy képviselőkön keresztül megjelenített igénye.

- A munkavállalók részvétele a vezetők véleménye szerint a kockázatkezelés sikerének kulcstényezője. A munkavállalói részvétel ezért a kockázatkezelés vállalati gyakorlata alakításának duplán hangsúlyos kérdése, melyben a magyar intézményekre jelentős feladat vár, miközben a jogi kötelezettségek betartásának szempontja tekintetében - egyedüli szempontként - az élen állók között található.

- A magyar jellemzők sok tekintetben a többi közép-kelet-európai, volt szocialista országéhoz hasonlóan, az európai átlag alatt, és az országok rangsorának utolsó harmadában találhatók . A magyar gyakorlatot tükröző vélemény sereghajtói pozíciót szinte sehol nem teremt, bár a rangsor élére is csupán egyetlen (kétes értékű) helyen állítja. Ez pedig, az egészségvédelem és a biztonság kérdése kezelésének indokai közül a legmagasabb aránnyal (97\%) elsőként jelölt: jogi előírások betartása. Mindezek egyúttal a kívánatos fejlesztés irányát is jelzik, melyek közül a hazai gyenge szintjük miatt kiemelendő a határozottabb vezetői és munkavállalói részvétel elérése.

\section{Az egészségtudatos vállalati magatartás diagnosztikai és fejlesztési modellje}

$\mathrm{Az}$ előző alfejezetekben áttekintettek alapján megállapítható, hogy az egészségtudatos vállalati magatartáshoz kapcsolódó programok, beavatkozások a 21. század második évtizedének közepén sem 
veszítettek aktualitásukból. Sőt, mivel Európa potenciális munkavállalóinak köre öregszik, emberi erőforrásai egyre korlátosabban állnak rendelkezésre, az egészség védelme, megőrzése a hosszabb távú gazdasági és társadalmi fejlődés egyik kulcskérdésévé lép elő. A kimenetek tekintetében az európai átlagtól való elmaradása okán különösen érvényes ez a közép-kelet-európai régió országaira, köztük hazánkra is.

Az egészség helyzete kapcsán az alakításában, alakulásában részes szereplők, színterek sokaságából e tanulmány csupán a munkahelyek szerepére fókuszál. Az egészségtudatos vállalati magatartásheterogén hazai gyakorlata ismeretében e célra olyan modellt tartunk hasznosnak, amely meghatározó elemei (dimenziói és lépcsőfokai) jellemezése alapján egy-egy szervezet beazonosíthatja, diagnosztizálhatja saját gyakorlatának aktuális szintjét, fokát, valamint a továbblépés, fejlődés, fejlesztés számára nyitva álló irányát és annak tartalmát. A következő alfejezetek egy ilyen modell alapelemeit vázolják fel.

\subsection{Az egészségtudatos vállalati programok kulcsdimenziói, a modell szerkezete}

A modell az egészségtudatos vállalati programokat két kritikus dimenzióra bontva azonosítja, ahol az

I. dimenzió az egészségtudatos vállalati magatartás olyan fokozatait, lépcsőfokait foglalja magában, amelyek a beavatkozások egészségformáláshoz kapcsolódó fő céljait, irányait jelenítik meg; és a

II. dimenzió pedig az egészségtudatos munkahelyi beavatkozások menedzselési fázisait, szervezeti státusz fokozatait öleli fel, amelyek a beavatkozások kulcsszereplőinek és hogyanjának lényegi módszertani sajátosságaira, eltéréseire világítanak rá.

E két dimenzió és fokozataik derékszögű koordinátarendszerbe rendezésével az origótól jobbra (y tengely I. dimenzió) és felfelé ( $\mathrm{x}$ tengely II. dimenzió) irányuló negyedében pedig kialakulnak az egészségtudatos vállalati programok modelljének potenciális alapelemei, a zöld zóna. Az origótól balra és lefelé irányuló térségbe a hiányos, elégtelen ismeretekre alapozó akciók, a törvényi előírások minimumát sem elérő, ám talán létező vállalati gyakorlatok kerülhetnek. Ennek a témakörünk szempontjából szürke, vagy fekete zónának a jellemzésével sem foglalkozunk, bár e helyzet megszüntetésének irányát, a zöld zónába kerülést már a modellkeret is mutatja. (Lásd 2. ábra!)

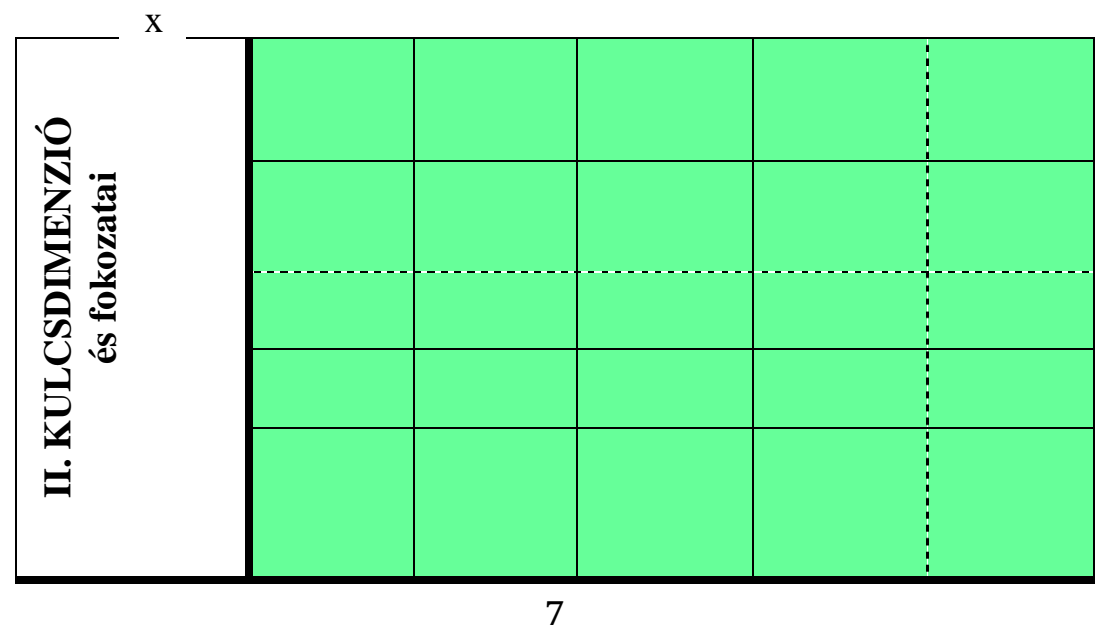




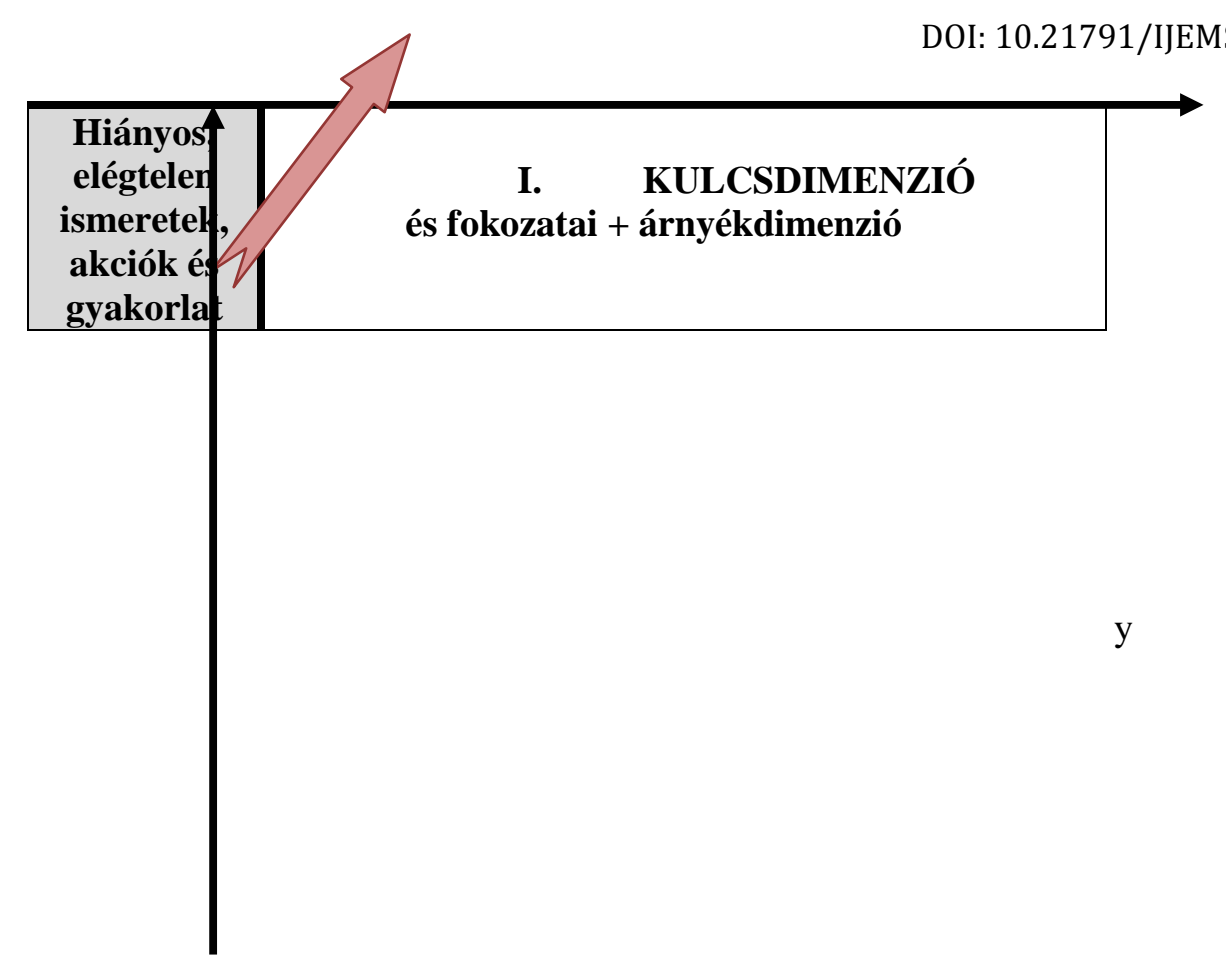

2. ábra: A kétdimenziós modell szerkezete

\subsection{Az I. kulcsdimenzió és elemeinek tartalma, jellemzői}

A modell I. kulcsdimenziója a fentiek értelmében az egészségtudatos munkahelyi magatartás fokozatait, lépcsőfokait megjelenítve az egészséget érintő beavatkozások történetileg is változó célterületeit tartalmazza. Ezek megkülönböztetése az egészség és az egészségmagatartásdefiniálására, valamint a munka, ill. a munkahely egészségre gyakorolt hatásai irányainak számbavételére épít.

- Egészségügyi Világszervezet (WHO) 1946-ban publikált definíciója szerint az egészség,,a tökéletes fizikai, szellemi és szociális jóllét állapota, és nem csak a betegség, vagy fogyatékosság hiánya."

Ezt a túl idealisztikusnak talált definíciót Bichner(2005, idézi Juhász, 2007) a következőképpen módosította:

„Az egészség a jóllét dinamikus állapota, melyet egy olyan fizikai, mentális és társas potenciál jellemez, amely kielégíti az egyén életkorának, kultúrájának és személyes felelősségének igényeit. Ha ez a potenciál nem elegendő az igények kielégítésére, akkor az állapot betegség."

E közelítés szerint az egyének egészsége a sors, az egyéni felelősség és a társadalmi támogatás összetett és dinamikus kölcsönhatásának eredménye. Az egyének egészségét támogatni, fejleszteni célzó programok ehhez igazodóan arra törekedhetnek, hogy az egyének vagy közösségeik képessé váljanak saját egészségük kontrollálására és ez által egészségi állapotuk és életminőségük javítására.

$\mathrm{Az}$ egészséget támogató programok egy része közvetve vagy közvetlenül az érintettek egészséggel kapcsolatos szokásainak, egészségmagatartásának megváltoztatását igyekszik elérni, amin olyan cselekvéseket érthetünk, melyek hatással lehetnek egészségünkre, addig, amíg még egészségesek vagyunk. Ezt érdemes megkülönböztetni a betegségmagatartástól, melynek célja az egészség helyreállítása, a közérzet javítása. 
- A munka, a munkahely egészségre gyakorolt hatása többirányú, hiszen a munka sokféle pozitív hatása mellett az egészséget veszélyeztető, károsító elemei is sokrétűek.

A munkának az egészségre gyakorolt negatív hatásai közé tradicionálisan olyan területek tartoznak, mint pl. a veszélyes, mérgező anyagok kezeléséből fakadó megbetegedések, a kedvezőtlen fizikai körülmények között végzett munka, a túlzott fizikai, vagy mentális igénybevétellel járó munkák, a munkahelyi balesetek.

Habár ezek döntő része évtizedek óta jól ismert, különböző intézmények által mért, felügyelt, ám korántsem megoldott, megszüntetett jelenség. Az egészségkárosító és az életet veszélyeztető negatív következményeik - nemcsak az újonnan megjelenő veszélyforrások - okán a 21. században is kiemelt figyelmet érdemelnek nem elsősorban azért, mert költségei is hatalmasak.

A munka és az egészségi állapot közötti negatív kapcsolat a 21. században leggyakrabban vizsgált és emlegetett formáját, a munkahelyi stresszt, a munkahelyi lelki egészséget veszélyeztető tényezők alkotják, melyek közé olyan elemek tartoznak, mint pl:

- a munka tartalmához és annak környezetéhez tartozó tényezők: az elvégzendő feladat jellemzőitől (pl. elaprózott vagy értelmetlen munka; a készségek kihasználatlansága), a munkaterhelés és a munkatempó sajátosságain (a mennyiségi, vagy minőségi túl-, vagy alulterhelés) át, a munkakörnyezet bizonyos jellemzőiig (a zaj; a hő; a túlzsúfoltság; az elvonulási lehetőségek hiánya (egyterü munkahelyek), stb.

- a szervezetben betöltött szerepekhez sorolható elemek: az egyéni szinten jelentkezőktől (pl. szerep-kétértelműség; túl sok, vagy túl kevés felelősség, autonómia; túlzott ütemű, vagy nem létező karriermozgások) a csoportszintűeken (jó munkahelyi kapcsolatok hiánya; csoporton belüli konfliktusok; zaklatás; munkahelyi pszichoterror, vagy mobbing;) át a szervezeti szinten (szervezeti légkör; vezetési stílusok; ellenőrzési rendszerek; az állás bizonytalansága stb.) érvényesülőkig terjednek.

A munkának az egészség szempontjából vannak, lehetnek pozitív hatásai is. Ezek akkor, illetve oly módon érvényesülnek, amennyiben a munka: jövedelmet hoz, növeli az önértékelést, társas kapcsolatok kiépítésére teremt lehetőséget úgy, hogy ezzel kielégíti az egyének eltérő életkori, kultúrához kapcsolódó és/vagy személyes felelősségszintjéhez igazodó igényeit.

Az egészségtudatos vállalati magatartás programjainak a fentiekben vázoltak szellemében legalább a munka negatív hatásainak csökkentésével, korlátozásával, ám korszerűbb közelítést követve azok megelőzésével éppúgy kell foglalkoznia, mint az egészség alakulására pozitívan ható beavatkozások érvényesülésének támogatásával. Megítélésünk szerint e tekintetben a munkahelyi megbetegedések, betegségek hiányát előidéző beavatkozások még korántsem idejétmúltak, így legalább olyan fontosak, mint az egészségre pozitívan ható megoldások, beavatkozások, akciók ismerete és alkalmazása.

A fenti megközelítések egyrészt rámutatnak a vállalatok egészségtudatos magatartását elváró indokok különbözőségeire, másrészt segítenek azonosítani egy-egy vállalati kollektíva egészségi színvonalának javításával kapcsolatos vállalati magatartások javasolt modellbeli három (1-3) fokozatát, majd pedig ezek további (A-E) belső lépcsőfokozatait. A három jól megkülönböztethető és a modellben is megjelenő fokozat a fentiek szerint tehát: 
1. A tradicionális közelítés, melynek fő céljaaz egészségkárosodások kontrollálása, csökkentése: a munka egészségre gyakorolt negatív hatásai érvényesülésének korlátozása, a megbetegedések csökkentése.

Itt a fő cél tehát a munkahelyi egészségkárosodások, megbetegedések csökkentése, melyet már a Luxemburgi Nyilatkozatban munkaegészség és munkabiztonság - ami a hazai munkavédelem, munkahigiéné hagyományosan érintett területeivel rokonítható - tradicionális közelítéseként újradefiniálásra érettnek minősítettek, amihez két belső fokozat rendelhető, melyek megkülönböztető sajátosságai:

(A) az egészséget károsító, veszélyeztető, hagyományosan a munkavédelem, a foglalkozás- és munkaegészségügy hatókörébe tartozó munkahelyi környezeti tényezők, jellemzők törvénybeli határértékeinek ismeretét, betartását, kontrollálását magába foglaló szabálykövető, ám passzív, a negatívumok korlátozására irányuló magatartásként jellemezhető;

(B) az egészséget károsító (túl/alul) terhelések következményeinek ismerete és törekvés a károsodás helyreállítására - a rekreáció garantálása miatt a negatív hatások kiegyensúlyozására irányuló reaktív magatartást fed.

2. MET/WHP - közelítés, melynek fő célja az egészségkárosodások megelőzése: a munkahelyi egészségkárosodások, megbetegedések, és az egyéni egészségromlás megelőzése, az egészségmegőrzés támogatása.

A munkahelyi egészségkárosodások, megbetegedések megelőzése, ami a 2007-ben aktualizált Luxemburgi Nyilatkozatban definiált munkahelyi egészséget támogató (azaz a MET, WHP) programok nevében az egészség szerepel ugyan, ám a megelőzést fókuszba állítva az egészségtámogató megoldások további két belső fokozatát eredményező megoldást pártfogol. Ezek:

(C)az egészséget veszélyeztető (túl/alul) terhelések ismerete és kockázatértékelésen alapuló kiiktatása, megelőzése alapján a potenciális veszélyek megelőző kiiktatása törekedve kockázatcsökkentő, proaktív magatartást jelenít meg;

(D) az egészséget és jóllétet támogató, integratív, kockázatcsökkentő, egyéni potenciál- és védelemfejlesztő szervezeti, munkahelyi környezet az egyéni egészségmegőrző programok pedig komplex, holisztikus magatartásnak minősíthetők.

3. Egészségmegőrző, -fejlesztő közelítés, ami a munkavállalói egészséget és jóllétet az egyéni egészségmegőrzés és a munka pozitív hatásai érvényesítésének együttes támogatásával célozza elérni és fokozni. A munkahelyi egészség fejlesztésének ez az útja miközben visszanyúlhat a megelőző (D) lépcsőfok főként az egyéni potenciál- és védelemfejlesztő egyéni egészségmegőrző programjai területére, ám kiegészülhet

(E)a munka pozitív hatásait erősítő, kiaknázó egészség- és jóllét-fejlesztő szervezeti és egyéni fókuszú programokkal, a hosszútávon fenntartható egészségmegőrzést célzó tényleges egészség-fejlesztő magatartással. 


\begin{tabular}{|c|c|}
\hline \multirow{2}{*}{$\begin{array}{l}\text { 1.Tradicionális } \\
\text { közelítés, } \\
\text { cél: } \\
\text { Az egészség- } \\
\text { károsodás } \\
\text { csökkentése }\end{array}$} & $\begin{array}{l}\text { az egészséget károsító, veszélyeztető munkahelyi környezeti tényezők, jellemzők } \\
\text { törvénybeli határértékeinek ismerete, betartása, kontrollálása } \\
\text { - szabálykövető, de passzív magatartás: a negatívumok korlátozása (A) }\end{array}$ \\
\hline & $\begin{array}{l}\text { az egészséget károsító (túl/alul) terhelések következményeinek ismerete és törekvés } \\
\text { a károsodás helyreállítására - rekreáció } \\
\text { - reaktív magatartás: a negatív hatások kiegyensúlyozása (B) }\end{array}$ \\
\hline \multirow{2}{*}{$\begin{array}{l}\text { 2. MET-közelítés, } \\
\text { cél: } \\
\text { Az egészség- } \\
\text { károsodás } \\
\text { megelőzése }\end{array}$} & $\begin{array}{l}\text { az egészséget veszélyeztető (túl/alul) terhelések, munkahelyi környezeti tényezők } \\
\text { ismerete és kockázatértékelésen alapuló kiiktatása, megelőzése - a potenciális } \\
\text { veszélyek megelőző kiiktatása } \\
\text { - proaktív magatartás: megelőzés, kockázatcsökkentés (C) }\end{array}$ \\
\hline & $\begin{array}{l}\text { az egészséget támogató integratív, kockázatcsökkentő és egyéni potenciál- és } \\
\text { védelemfejlesztő szervezeti, munkahelyi környezetre és egyéni egészségmegőrzésre } \\
\text { együttesen építő programok } \\
\text { - komplex, holisztikus magatartás:támogatás (D) }\end{array}$ \\
\hline $\begin{array}{l}3 . \quad \text { Egészség- } \\
\text { megőrző/fejlesztő } \\
\text { közelítés }\end{array}$ & $\begin{array}{l}\text { a munka pozitív hatásait erősítő, kiaknázó egészség- és jóllét-fejlesztő szervezeti és } \\
\text { egyéni fókuszú programok } \\
\text { - aktív pozitív magatartás: fejlesztés (E) }\end{array}$ \\
\hline
\end{tabular}

1. táblázat: Az egészségtudatos munkahelyi magatartás fokozatai és lépcsőfokai

A kétdimenziós modell előzőekben bemutatott I. dimenziójának fokozataiba illeszkedően megjeleníthető az a kétfókuszú árnyékdimenzió, melyek elemei vagylagosan, illetve az ezredfordulótól egymással ötvözve is érvényesülnek. Ennek területei a következők:

- az egyénre irányuló akciók (az egészség munkahelyi támogatása, EMT), melyek az egyének, a munkatársak egészségtudatos magatartását, egészségi állapotát kontrolláló, támogató ismeretek, akciók kialakítását, elérhetővé, hozzáférhetővé tételét célozzák; és

- a fizikai és szervezeti munkakörnyezetre irányuló akciók (a munkahelyi egészség és jóllét támogatása MET), melyek főként a munkahelyi egészséget és biztonságot valamint jóllétet befolyásoló szervezeti környezet és a munkafeltételek alakítását támogató folyamatok, rendszerek kiépítését és eredményes működtetését öleli fel.

Az egyénekre irányuló akciók az USA-ból eredő közelítés megtestesítői, mivel ott az uralkodó szemlélet szerint a dolgozók maguk felelősek egészségügyi problémáikért, a vállalatok egészséggel kapcsolatos feladata kimerül abban, hogy segítséget nyújtanak nekik a jobb egészségi állapot eléréséhez. Ezért az egészség munkahelyi támogatása ott arra fókuszált, hogy megfelelő ismeretbővítő, készségfejlesztő, viselkedésváltozást szorgalmazó programokat kínáljanak az alkalmazottaknak.

Az Európában érvényesülő szemlélet értelmében viszont a munkáltató felelős az egészséget és biztonságot nem veszélyeztető fizikai és mentális körülmények kialakításáért, azaz itt sokáig a második, a fizikai és szervezeti munkakörnyezetre irányuló közelítés érvényesült. 
Az ezredforduló környékétől az egészségtudatos vállalati magatartás immáron a két eltérő fókuszú és eszközrendszerű közelítés együttes, egymást támogató, kiegészítő lehetőségeinek kiaknázását propagálja.

\subsection{A II. kulcsdimenzió és elemeinek tartalma, jellemzői}

Az egészségtudatos vállalati fejlesztési programok modelljének II. kulcsdimenziója az e fejezetben már vázoltak szerint az egészségtudatos munkahelyi beavatkozások, akciók, folyamatok menedzselési módjait, szervezeti státusz fokozatait (szeparált-integrált) és lépcsőfokait, (A-E) foglalja magában, melyek a beavatkozások hogyanjának lényegi eltérései, módszertani sajátosságai is hozzárendelhetők.

Ahogyan az I. dimenzió esetében tettük, a gyakorlatban előforduló magatartások most a II. szempontrendszer kapcsán is a pozitív tartományba sorolhatóakkal indítjuk. Eszerint léteznek:

1. A spontán módon alakuló, vagy a vállalati stratégiai és operatív tervekbe nem integrált, ám a felelősségi körében néhány szakmailag kompetens szereplő által szervezett, de a cég HR rendszereitől és menedzsment folyamataitól és struktúrájától elkülönülten, attól szeparáltan megvalósuló egészségtudatos tevékenységek, akciók. Ezek egyre gazdagabb, korszerűbb fokozatai:

(A)a munkahelyi egészség támogatására (MET) és/vagy az egészség munkahelyi támogatására (EMT) fókuszáló eseti tevékenységek, akciósorozatok (olyanok, mint pl. az egyéni munka-alkalmassági vizsgálatok, vagy egy-egy vállalati szűrőprogram vagy sportnap);

(B) az egyedi, de professzionális, a munkahelyi egészség támogatását, fejlesztését (MET) és/vagy az egészség munkahelyi támogatását (EMT) tervezetten megvalósítani célzó tevékenységlánc(ok) (pl. kockázatértékelés a munkabiztonsági szakember és a foglalkozásegészségügyi orvos hatókörébe utalt módon, illetve egészségterv-készítés alapján szervezett programok, pl. bringázz a munkába akcióban való részvétellel);

(C) előfeltételekkel integrálódó, ám folyamatos, a munkahelyi egészség támogatását (MET) célzó szisztematikusan irányított (P-D-C-A) ciklusok szerinti működés.

2. Az integrált egészségtudatos beavatkozások, folyamatok, melyekre a cégvezetés, és/vagy a vállalati HR munka természetes részeként tekintenek. Ezek fokozatai tehát amikor:

(D) a felső vezetés elkötelezett az EMT ügyében, és a MET mind az operatív mind a stratégiai felsővezetői megfontolások, döntések természetes részét képezi;

(E) a programfejlesztésekben való aktív munkavállalói, ill. képviselői részvétel, participáció révén, melynek eredményeként a MET és az EMT egyaránt a HR munka természetes és minden HR funkciót érintő részévé válik, a vállalati HR stratégiába, rendszerekbe, alkalmazott módszerekbe illesztve van jelen a cég életében.

A II. dimenzió két megkülönböztethető jellemzővel bíró eleme tehát az egészségtudatos beavatkozások szeparált jelenléte, vagy a szervezet irányítási rendszerébe és más, stratégiai jelentőségű funkcionális területeibe integrált megvalósulása. Ezt és ennek belső fokozatait jeleníti meg a 2. táblázat. 


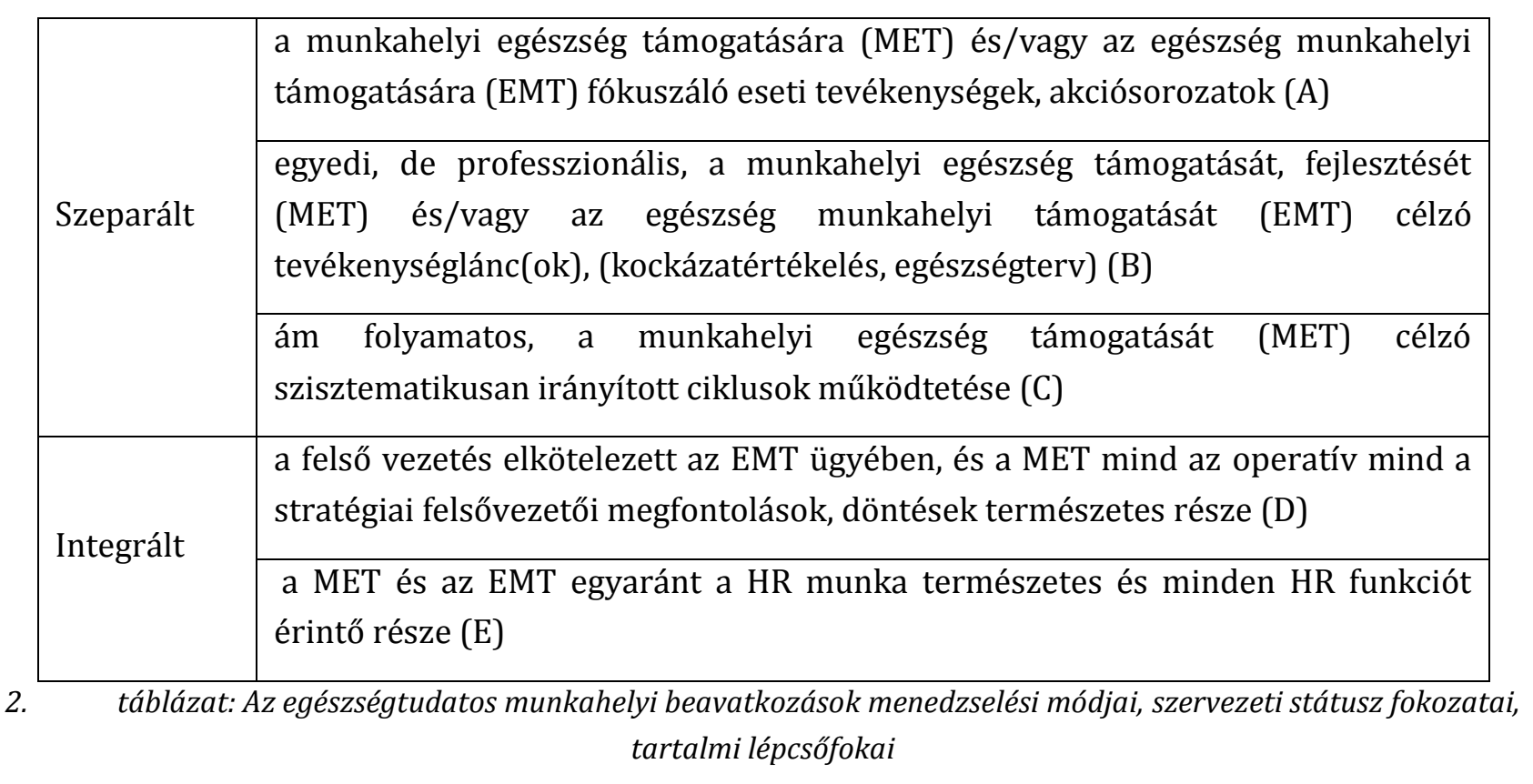

\subsection{A modell és gyakorlati alkalmazási lehetőségei: öndiagnózis és testreszabott fejlesztési irány-választás}

Az I. dimenzió 3 fokozatának az előző alfejezetben megkülönböztetett 5 belső lépcsőfokából $a z$ első három (A-C) - az egészséggel kapcsolatban a negatívumok, azaz a veszélyek, betegségek passzív, reaktív vagy proaktív - követésének gyakorlata nevezhető vállalati betegségmagatartásnak, míg az utolsó két lépcsőfok (D-E) tekinthetô vállalati egészségmagatartásnak. A köztük húzható határvonalat az egészségtudatos vállalati programok modelljének 2. ábráján a programlépcsőfokok közé húzott szélesebb függőleges vonal jelzi.

A II. dimenzió 2 fokozata a másik kritikus szempont, ami szerint a betegséggel és vagy az egészséggel kapcsolatban végzett tevékenységek, folyamatok és felelőseik a vállalati élet stratégiailag fontos, üzleti megfontolásai és a szervezeti hierarchia csúcsa körül megjelenő, a vagy azoktól távol eső szereplőihez, folyamataihoz kapcsolódnak-e. Azaz azokba integráltan, vagy tőlük szeparált módon valósulnak-e meg. A 3. ábrán e különbséget a vízszintes szaggatott vonal jeleníti meg. 


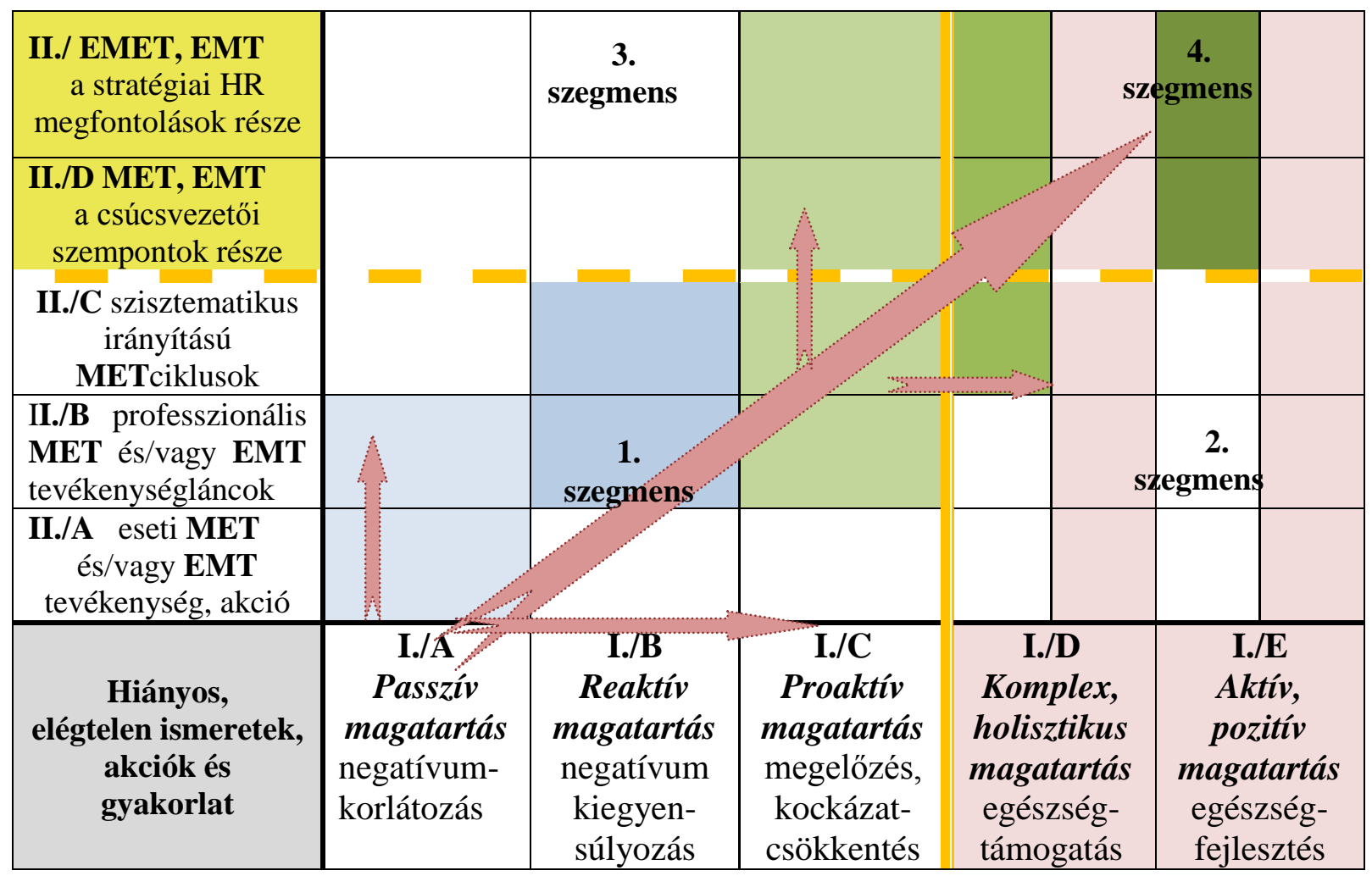

3. ábra: Az egészségtudatos vállalati magatartások fejlesztési modellje

Az 1. szegmens oszlopai a jobbra mutató nyíl irányában (I./A-tól I./C-ig) az egyre korszerübb és sokrétűbb vállalati betegségmagatartás-célok teljesítéséhez vezető tartalmakat jelenítik meg. Ahogy azt a modell ábrája szemlélteti, az eltérő tartalmakhoz tipikusan párosuló„hogyanok” azaz megoldási módok, módszertani megoldások kapcsolhatók. Az I./A-hoz, azaz a negatívumokat korlátozó magatartás jellemzően szeparált, eseti akciók, tevékenységek (II./A) révén valósul meg. Az ebbe a modellelembe tartozó vállalat gyakorlatán javíthat vagy az alkalmazott folyamat és módszertan fejlesztésével (a felfelé mutató nyíl irányában) a II./B elembe lépve, és/vagy a megcélzott betegségmagatartások fejlettebb verzióinak (I./B, I./C) választásával.

Az 1.-ből jobbra, a 2. szegmensbe lépve a szeparáltan megvalósuló egészségmagatartás programjai a szervezeti betegség-magatartások mellett, azokkal párhuzamosan, vagy attól függetlenül is érvényesülnek. Az egészségmagatartás két lépcsőfoka az árnyékdimenzió érvényesülése miatt további két részre bomlik. Az egészség munkahelyi támogatását célzó egyéni fókuszú beavatkozások, ahogy azt a modell eltérő színű függőleges sávjai jelzik, bármelyik II. dimenziós státuszfokozat mellé párosulhat.

A felfelé irányuló szegmensváltás (3. szegmens) pedig az egészségtudatos koncepció szervezeti fókuszú gyakorlatának vállalati megfontolások közé integrálását hozhatja. A kettős (egyéni és szervezeti) célpontú közelítés megjelenésének és integrálásának feltételei pedig a modell 4 . szegmensében vannak jelen, amihez felsővezetői elkötelezettség és az ezt szakmailag jól támogató stratégiai HR munka szükséges. 


\subsection{Az egészségtudatos munkahelyi beavatkozások szervezeti státusz- fokozatainak és menedzselési folyamatainak módszer és eszközkészlete}

Ez az alfejezet csupán vázlatszerűen utal arra a módszer és eszközkészletre, amelyek segítségével az egészségtudatos erőforrás-fejlesztési programok folyamatai megvalósíthatók, irányíthatók, a vállalkozások üzleti folyamataiba integrálhatók. A programtípusokat a 3. ábra modelljében szereplő II. dimenzió egymást követő fokozatai szerinti struktúrában említjük.

- A munkahelyi egészség támogatására (MET) és/vagy az egészség munkahelyi támogatása (EMT) fókuszáló tevékenységek, akciósorozatok (a modell II. dimenziójának első, azaz A fokozata) gyakran csupán eseti megoldásokként, szeparáltan vannak jelen a vállalkozások életében.

Ide sorolhatók például az egyéni munka-alkalmassági vizsgálatok, vagy egy-egy vállalati szűrőprogram vagy az esetenként megrendezett egészség-, vagy sportnapok, bringatúrák. Ezek a szeparáltan megvalósuló eseti tevékenységek, ad hoc akciók lehetnek szervezeti, betegségkorlátozó és/vagy egyéni, egészségtámogató fókuszúak is. Ez utóbbiak leggyakoribb megjelenési formái, tartalmai láthatók a 4. ábra képgyüjteményében.

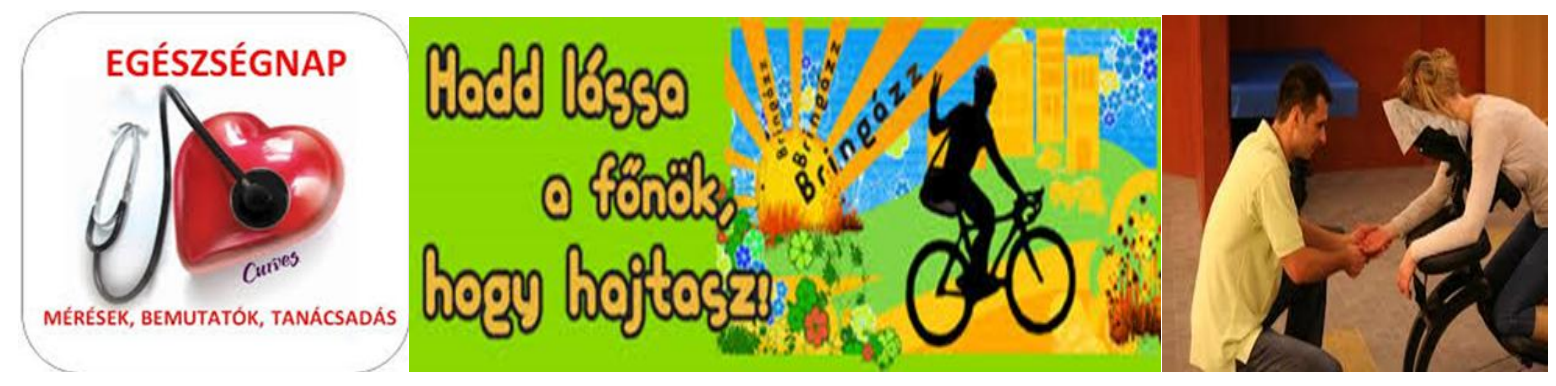

4. ábra: Az egészség munkahelyi támogatásának jellegzetes programjai

- A modell következő, (B) lépcsőfoka az egyedi, de professzionális, a munkahelyi egészség támogatását, fejlesztését (MET) és/vagy az egészség munkahelyi támogatását (EMT) célzó, tevékenységláncokat foglalja magában. A modell első (A) lépcsőfokán megjelenő beavatkozásokhoz képest tehát elsősorban nem tartalmukban eltérő, hanem szisztematikusan tervezett és szakszerúen mérlegelt, jól megválasztott módszereket alkalmazó megoldásokról van szó. Ezek közé sorolható: a kockázatértékelés és az egészségterv.

A kockázatelemzés és egészségterv készítés és megvalósítás hazai szakirodalomban fellehető jellemzők alapján megállapítható, míg az első alapvetően a munkahelyi egészség megőrzésének, támogatásának (MET) szervezeti fókuszú, betegség-magatartás jellegű programjait, addig az egészségterv(ek) inkább az egészségtudatos erőforrás-fejlesztési programok másik ágát, az egészség munkahelyi támogatását (EMT) célzó, egyéni fókuszú folyamatait támogatják.

- A modell következő(C) és azt követő lépcsőfokaiba illeszkedő megoldások szisztematikus-ciklikus irányításuk révén a folyamatok szeparáltságának megszüntetését ígérik, illetve a vállalkozások emberi erőforrásai menedzselésének szerves részeként valósítják meg a munkavállalók egészségtudatos kezelését.

Itt aPDCA ciklus szerinti vállalati egészség- és biztonság-irányításmódszerétemeljük ki és főbb jellemzőit az 5. ábrán látható elemei segítségével vázoljuk. 


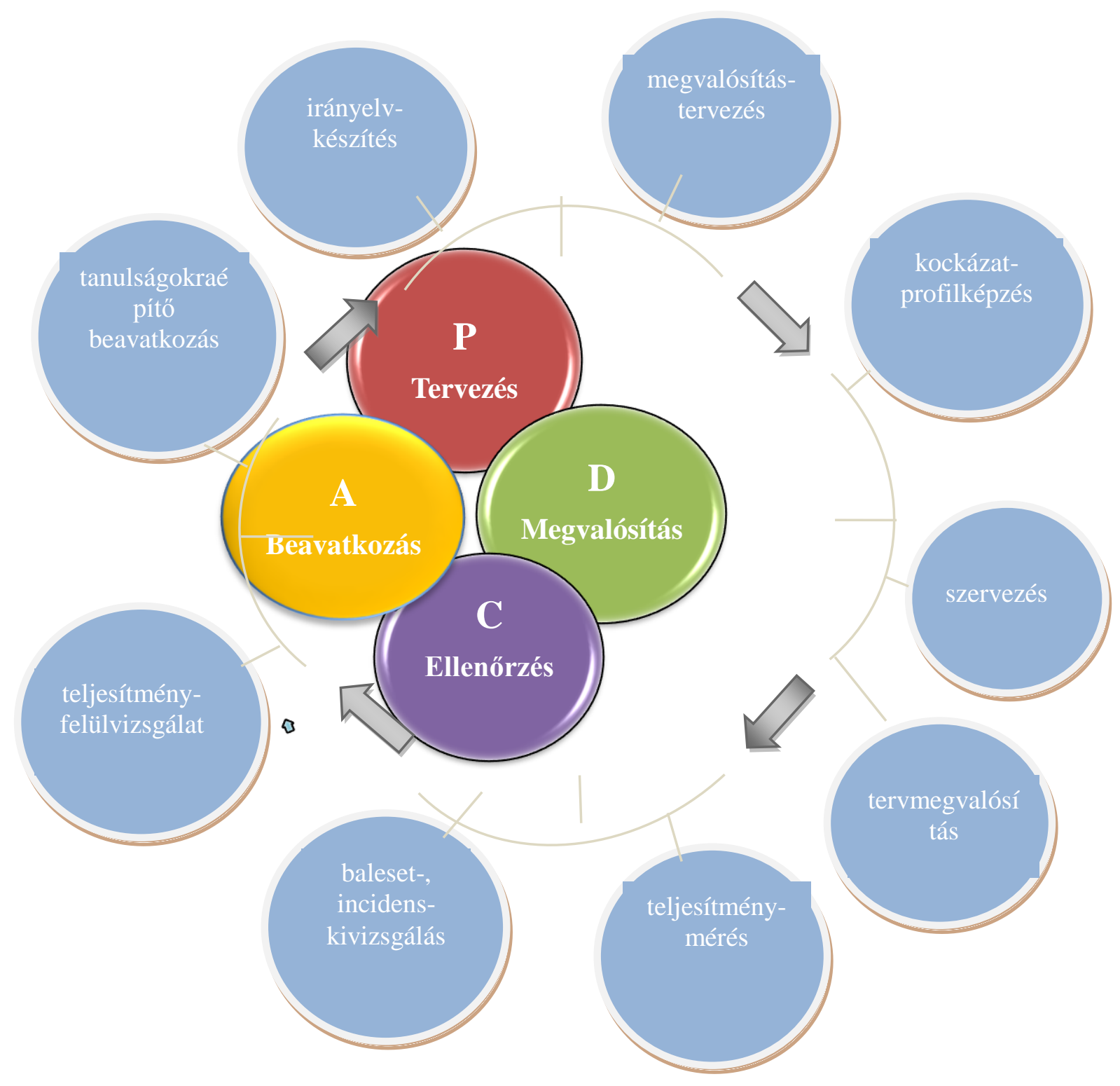

5. ábra: A PDCA ciklus és a munkahelyi egészséget és biztonságot támogató részelemei

(Forrás: HSE (2013): Managing for Health and Safety. (3. Ed.)UK)

A PDCA-közelítés sajátosságaként hangsúlyozzuk, hogy aUK-ben megfogalmazott dokumentumában a kooperáció, a munkatársaknak a jogszabályi elvárásokban szereplő konzultációt meghaladó bevonásának olyan gyakorlatára utal, amit a vezetők és munkatársak kölcsönös tiszteletre és bizalomra építő együttműködése jellemez. Ilyen partneri szerep mellett van esély az E\&B terén jelentkező problémák közös megoldására, és arra, hogy az aggodalmak, ötletek és megoldások szabadon felszínre kerüljenek és érvényesüljenek.

A munkatársak (köztük a vezetők) ilyen bevonása kulcseleme az ME\&B mindennapi üzleti ügyekbe történő integrálásának. Így biztosítható, hogy egy szervezetben az egészség és biztonság ügyeire ne úgy tekintsenek, mit ami „valaki más” feladata. 
A munkatársak, egy-egy szervezet emberi erőforrásai egészségének, biztonságának és jól-létének komplex érvényesítése és érvényesülése viszont akkor várható legteljesebb mértékben (melynek révén elérhetünk a modell 4 szegmensébe) ha ezek a szempontok a tudatos és koherens tervezés és megvalósítás során az emberi erőforrások menedzselési rendszereibe (Karoliny-Poór, 2010)is beépítésre kerülnek. Érdemes megkülönböztetni az adminisztratív személyzetmenedzselés gyakorlatától azt a proaktív, stratégiai emberi erőforrás menedzselési közelítést, melynek a „just-inhealth", azaz az aktuálisan igényelt munkatársi egészséget biztosító stratégiája (az Európában várható demográfiai kihívások miatt sem) a buy hanem inkább a make verzióra épít. A modellben vázolt lehetséges egészségtudatos magatartásformák közül ez a stratégia a munkatársak hosszú távú egészség-megőrzésének, -fenntartásának ösztönzését, az egyéni és a szervezeti fókuszú beavatkozásokkal (EMT+MET) történő támogatás révén megvalósuló vállalati egészségmagatartás követését igényli.

\section{Összefoglalás}

Hogy az egészség miért nem csak az egészségügy ügye, azaz, hogy miért tekinthető és kezelendő a 21. század elején a munkahely az egészségalakulás színterének, a tanulmány a nemzetközi és európai csúcsintézményekben született dokumentumok áttekintésével mutatta be.

A 21. százaz eleji európai és a magyar helyzetjellemzők, a tények és a vélemények azt igazolják, hogy bár a munkahelyi egészség és biztonság kérdésköre nem új keletű a vállalatok életében, nemcsak az ettől tágabb értelmű, komplexebb munkahelyi egészségtámogatás terén találhatóak gyenge pontok a vállalkozások gyakorlatában.

A tanulmány súlyponti fejezete némi fogalmi tisztázásokra alapozva egy modellépítő alfejezettel kezdődött. Tette ezt azért, hogy a tárgykör iránt érdeklődő, de az egészségtudatos vállalati magatartások eltérő fejlettségi szintjén álló vállalatok számárafejlesztési irányt, lehetőségeket vázoljon. A modell két kulcsdimenziója és azok fokozatainak jellemzése lehetővé teszi, hogy az e téren magatartásváltoztatást tervezők cégük egészségformáláshoz kapcsolódó fő céljai, irányai, valamint kulcsszereplőik és hogyanja,módszertani sajátosságai alapján meghatározhassák gyakorlatuk „vanállapotát” és kijelölhessék annak „kell-állapotát”, a beavatkozások kívánatos fejlesztés irányát és lehetséges módját.

\section{Hivatkozások}

[1] A Bizottság közleménye az Európai Parlamentnek, a Tanácsnak, az Európai Gazdasági és Szociális Bizottságnak és a Régiók Bizottságának az Európai Unió munkahelyi biztonsággal és egészségvédelemmel kapcsolatos, 2014-2020-as stratégiájáról, EURÓPAI BIZOTTSÁG, Brüsszel, 2014.6.6. COM (2014) 332 final

[2] EU-OSHA (2010), ESENER Új és újonnan felmerülő kockázatokról szóló európai vállalati felmérés, Összefoglaló, Európai Kockázatkutató Központ, Bilbao, Spanyolország 
[3] EU-OSHA (2012), The currentstate of theoccupationalhealth and Safetyin Europe, October, Nicosia http://www.slideshare.net/euosha/the-current-state-of-occupational-safety-andhealth-in-europe

[4] EU-OSHA (2013), A munkabalesetek és foglalkozási megbetegedések költségeinek becslése, Vezetői összefoglaló / Executivesummary - Estimatingthecost of accidents and illhealthatwork. Publications Office of the European Union, Luxembourg, ISBN: 978-929240-244-0

[5] Európai Munkahelyi Biztonsági és Egészségvédelmi Ügynökség, Egészséges munkahelyek. Kezeljük a stresszt. Kampányútmutató. A munkahelyi stressz és a pszichoszociális kockázatok, https://www.healthy-workplaces.eu/hu?set_language=hu

[6] FEHÉR KÖNYV (2007), Együtt az egészségért: Stratégiai megközelítés az EU számára 20082013, AZ EURÓPAI KÖZÖSSÉGEK BIZOTTSÁGA Brüsszel, 23.10.2007 COM

[7] Guidelines on occupational safety and health management systems (2009), ILO-OSH 2001 (2. Ed.) ILO, Geneva http://www.ilo.org/wcmsp5/groups/public/---ed_protect/--protrav/---safework/documents/normativeinstrument/wcms_107727.pdf

[8] HSE, Managingforhealth and safety, Health and SafetyExecutive, (3. Ed.) UK http://www.hse.gov.uk/pubns/priced/hsg65.pdf, 2013.

[9] M. Karoliny, J. Poór (szerk.) (2010), Emberi erőforrás menedzsment kézikönyv, Rendszerek és alkalmazások, 5. átdolgozott kiadás, Complex Kiadó Jogi és Üzleti Tartalomszolgáltató Kft. Budapest

[10] LUXEMBOURG DECLARATION on Workplace Health Promotioninthe European Union, ENWHP Version of January 2007.

[11] Munkahelyi egészségfejlesztési programok szakmai útmutatója a Társadalmi Megújulás Operatív Program Egészségre nevelő és szemléletformáló életmód programok - lokális színterek című pályázati felhívásához Kódszám: TÁMOP - 6.1.2/11/1

[12] PLANOF ACTION, toachievewidespreadratification and effectiveimplementation of theoccupationalsafety and healthinstruments (ConventionNo. 155, its 2002 Protocol and ConventionNo. 187) AdoptedbytheGoverning Body of the International Labour Organization atits 307th Session (March 2010) International Labour Office, Geneva, 20102016. 